\title{
Identification and Quantification of Sodium Benzoate in Different Brands of Mango Juices Available in Tangail Region, Bangladesh
}

\author{
Shamoli Akter ${ }^{1}$, Md. Abu Zubair ${ }^{1}$, Md. Shahinul Haque Khan ${ }^{2 \dagger}$, Luthfunnesa Bari ${ }^{2 \dagger}$, \\ Md. Azizul Huq ${ }^{1 \dagger}$ and Mohammad A. Rashid ${ }^{3}$ \\ ${ }^{1}$ Department of Food Technology and Nutritional Science, Mawlana Bhashani Science and Technology University, \\ Santosh, Tangail-1902, Bangladesh \\ ${ }^{2}$ Department of Chemistry, Bangladesh University of Health Sciences, Mirpur-1, Dhaka, Bangladesh \\ ${ }^{3}$ Department of Pharmaceuticals Chemistry, Faculty of Pharmacy, University of Dhaka, Dhaka, Bangladesh
}

Received: September 29, 2016; Accepted: October 19, 2016; Published (Web): March 19, 2017

\begin{abstract}
Chemical preservation has become an increasingly important practice in modern food technology. Sodium benzoate is a permitted food additive in restrictive amounts by international laws, but their content must be declared and must not exceed the established limits by legislation. An experimental study for the level of sodium benzoate in different brands of mango juices available in the markets, stores and shops in Tangail region of Bangladesh was determined by high performance liquid chromatography. A Luna $5 \mu \mathrm{C} 18$ (2) $100 \mathrm{~A}$ column $(250 \times 4.6 \mathrm{~mm})$ was used for the chromatographic analysis. Chromatographic separation was achieved with isocratic solvent system comprising of sodium acetate and acetic acid buffer $(\mathrm{pH}$ $=4.0) /$ acetonitrile in the ratio of $80: 20(1 \mathrm{ml} / \mathrm{min})$ at $37^{\circ} \mathrm{C}$ and the chromatograms were recorded at $254 \mathrm{~nm}$. The limit of detection and quantification for sodium benzoate was $0.00076 \mathrm{mg} / 100 \mathrm{ml}$ and $0.00231 \mathrm{mg} / 100$ $\mathrm{ml}$, respectively. Quantification of the selected brand juices revealed that the level of the used sodium benzoate was within the FDA standard range. But by comparing with the Bangladesh Standard and Testing Institute (BSTI), brand-1 and brand-3 of the analyzed juice samples was found to deviate the current legal limits. The percentage recovery was found to be $92.04 \pm 1.98$ to $98.01 \pm 1.91$. It was found that some of the brands used excess amount of sodium benzoate which may be harmful for our health.
\end{abstract}

Key words: Preservatives, Sodium benzoate, HPLC, Identification, Quantification.

\section{Introduction}

Food additives have become increasingly important in modern food technology (Rahman et al., 2015; Saad et al., 2005). The demand for new, tasty, convenient and nutritious foods continued to increase the early days of processed foods and beverages (Sloan, 2004). It is estimated that over 2500 different additives are currently being used in food products (Branen et al., 2002). Food additives are used for various purposes, including preservation, coloring, and sweetening. The preservatives are added to stop or delay nutritional losses due to microbiological, enzymatic or chemical changes of foods and to prolong the shelf life and quality of foods. Benzoic acid and its salts such as sodium, potassium and calcium benzoates are normally preferred and used as food preservatives. They are normally represented by E- numbers such as E210benzoic acid, E211- sodium benzoate, E212- potassium benzoate and E213- calcium benzoate. Sodium benzoate is one of the most acceptable food preservatives that is allowed by the Bangladesh Standard Authority to use in the non-alcoholic beverages in Bangladesh. Although sodium benzoate is generally recognized as safe (GRAS), short-term exposure to sodium benzoate can irritate the eyes, skin and the respiratory tract. And long-term exposure or repeated exposure may cause skin sensitization. Children are at higher risks as they have high quantity intake per $\mathrm{kg}$ body weight with different dietary patterns and food preferences. About $80 \%$ of benzoic acid and its salts exposure to children (youth) are from soft drinks and prepackaged beverages. In fact,

Correspondence to: Mohammad A. Rashid, E-mail: rashidma@du.ac.bd, ${ }^{\dagger}$ These authors contributed equally to this work. 
carbonated water-based flavored drinks, soft drinks and fruit drinks are major contributors to the benzoic acid exposure in teenagers because of their high consumption levels of these products. Adverse effects include asthma, urticaria, metabolic acidosis, convulsions and so on (Tfouni and Toledo, 2002; (WHO, 1996). The development of allergic reactions to benzoates in humans, such as urticaria, nonimmunological contact urticaria and asthma, has been reported in some studies (Hannuksela and Haahtela, 1987; Juhlin, 1981; Juhlin et al., 1972; Lahti et al., 1987; Michaelsson and Juhlin, 1973; Rademaker and Forsyth, 1989; Safford et al., 1990). Sodium benzoate is a permitted food additive by the international laws in restrictive amounts for processed foods and nonalcohol, but their content must be declared and must not exceed the established limits by legislation.

Under the provisions set by the US Food and Drug Administration (FDA) in the code of Federal Regulations, food additives can be used if they are generally recognized as safe (GRAS) and declared on the label. For instance, sodium benzoate may be used as a preservative in juices, however, its usage should not result in levels exceeding $0.1 \%$ (CFR 1999). In Bangladesh, BSTI reference value for sodium benzoate is $150.0 \mathrm{mg} / \mathrm{kg}$ (Kayshar el al., 2014). In this study, a simple method that provides accurate results for sodium benzoate in different brands of mango juices is presented. The method uses a simple dilution for sample preparation followed by detection and determination by high performances liquid chromatography equipped with UV-detection.

\section{Materials and Methods}

Reagents: HPLC grade acetonitrile and sodium acetate $(97 \%)$ were purchased from Merck, Darmstradt, Germany; glacial acetic acid and anhydrous sodium benzoate were purchased from Sigma Chemical Co., Germany. De-ionized water (18.2 $\mathrm{M} \Omega$ ) used for chromatography was prepared by using Barnstead Nanopure water purification system (Barnstead, USA).

Materials: Different brands as well as different batches of mango juices were purchased from local markets and super markets in Tangail town, Bangladesh. A total of twenty seven samples were collected for the experiment of sodium benzoate analysis. The expiry dates of all samples were within the study period. The volumes of the samples were $250 \mathrm{ml}$ (7 Brands) and $500 \mathrm{ml}$ (2 Brands). The collected samples were preserved in a refrigerator until analysis.

HPLC system: The HPLC system equipped with a Shimadzu isocratic pump (10Avp), a degasser, column, oven, a UV-Vis detector a LC Workstation Class-VP were used for data acquisition and analysis. Twenty microlitre $(20 \mu \mathrm{l})$ of sample were injected into the injector. A Luna $5 \mu \mathrm{C} 18$ (2) $100 \AA$ column $(250 \times 4.6$ $\mathrm{mm}$ ) was used for the chromatographic separation at $37^{\circ} \mathrm{C}$. The sodium benzoate analysis was performed with isocratic solvent system using sodium acetate and acetic acid buffer $(\mathrm{pH}=4.0) /$ acetonitrile 80:20 with a flow rate of $1.0 \mathrm{ml} / \mathrm{min}$. Chromatograms were recorded at $254 \mathrm{~nm}$.

Mobile phase preparation: The mobile phase comprising of $80 \%$ acetate buffer with $20 \%$ HPLCgrade acetonitrile was prepared using the modified method (Pylypiw and Grether, 2000). One ml of glacial acetic acid and $1000 \mathrm{mg}$ of sodium acetate were taken in a $1000 \mathrm{ml}$ volumetric flask containing about $50 \mathrm{ml}$ de-ionized water and shaken well. Finally, the deionized water was added up to the mark to make 1000 $\mathrm{ml}$ and was mixed well. $200 \mathrm{ml}$ of acetonitrile was added to $800 \mathrm{ml}$ of the acetate buffer solution and was mixed well. The mixture was filtered with a nylon-66 filter membrane, pore size $0.2 \mu \mathrm{m}$.

Preparation of standard solution of sodium benzoate: Exactly $50 \mathrm{mg}$ of anhydrous sodium benzoate was taken in a $50 \mathrm{ml}$ volumetric flask. $20 \mathrm{ml} 50 \%$ aqueous acetonitrile was added to the volumetric flask and was shaken well. Finally, 50\% aqueous acetonitrile was added up to the mark. The solution was filtered with a syringe filter. The standard stock solution-1 was labeled as $1.0 \mathrm{mg} / \mathrm{ml}$. Four $\mathrm{ml}$ of stock solution-1 was taken in a $50 \mathrm{ml}$ volumetric flask and mobile phase was added up to the mark and was mixed well. The solution-2 was labeled as $80 \mu \mathrm{g} / \mathrm{ml}$ standard solution.

Aliquot of $0.0,62.5,125,250$ and $500 \mu 1$ of each standard solution-2 was taken into an Eppendorf tubes and was diluted to volume $1.0 \mathrm{ml}$ with mobile phase and mixed well with a vortex mixer. 
Preparation of sample solution: Exactly $5.0 \mathrm{ml}$ of mango juice was added in a $50 \mathrm{ml}$ volumetric flask. Aqueous $50 \%$ acetonitrile was added up to the mark and mixed well. $10 \mathrm{ml}$ of the solution was taken in another $50 \mathrm{ml}$ volumetric flask and added the same solvent up to the mark. The sample concentration was labeled as $20 \mu \mathrm{l} / \mathrm{ml}$. Approximately $1.5 \mathrm{ml}$ of the solution was filtered with sample filter (pore size 0.2 $\mu \mathrm{m})$ to an Eppendorf tube. Exactly $20 \mu \mathrm{l}$ of this sample mixture was injected onto the HPLC column.

\section{Experimental}

Analysis of sodium benzoate: A high performance liquid chromatographic technique was used to determine the concentration of sodium benzoate in the samples by using the modified the method described by Pylypiw and Grether (2000). Each of juice samples of $1.0 \mathrm{ml}$ was diluted (1:5) with mobile phase which was further diluted to 1:10 with the mobile phase. The diluted mixture was transferred into dry Eppendorf tube and centrifuged for $15 \mathrm{~min}$. The clear aqueous solution was filtered through a PTFE syringe filter. Then the solution was transferred to the dry HPLC vials and was injected to the column for detection and quantification.

Optimization: UV-spectrophotometer was used to determine the times of sodium benzoate. The $\lambda_{\max }$ for sodium benzoate was found to be at $254 \mathrm{~nm}$. Therefore, the HPLC analyses were carried out at $254 \mathrm{~nm}$.

Calibration curve: The external standard calibration method was used to get a calibration curve. Then $20 \mu \mathrm{l}$ of each standard solutions ( $0.05 .0,10.0$, 20.0 and $40.0 \mu \mathrm{g} / \mathrm{ml}$ ) were injected. The peak areas were measured and those of the analytes (y) were plotted against the concentration $(\mu \mathrm{g} / \mathrm{ml})$ of the sodium benzoate $(\mathrm{x})$. Least square linear regression analysis was used to determine the slope, y-intercept and the correlation coefficients of the standard plots.

Quantification: The Shimadzu HPLC equipped with SHIMADZU CLASS-VP chromatographic data system as the software was used for the calibration curve and the quantification of the samples. The quantification of the samples was based on comparison of the peak areas of the standard with those of the samples.
Limit of detection and quantification: The limit of detection (LOD) is the lowest amount of analyte in a sample which can be detected but not necessarily quantified as an exact value while the limit of quantification (LOQ) refers to the lowest level of analyte which can be determined with an acceptable degree of confidence. In this work the detection limit (LOD) and quantification limit (LOQ) values were calculated based on standard deviation of the response and the slope of the calibration curve [ICH 1996]. The concentration was multiplied by 3 and 10 to obtain the limit of detection and quantification, respectively.

HPLC analysis: For HPLC method validation the following performance parameters were calculated: precision, linearity, detection limit, quantification limit, also the expanded uncertainty. The precision of the analytical method was evaluated by measuring the chromatographic peak area of sodium benzoate three times for the same sample. Peak areas from HPLC chromatogram were plotted against the known concentrations of stock solutions of varying concentrations.

Recovery study: In order to verify the accuracy and precision of the analytical procedure, recovery studies were carried out by spiking some samples with very low levels of sodium benzoate $(2.5 \mathrm{mg} / \mathrm{l}, 5 \mathrm{mg} / \mathrm{l}$, and $7.5 \mathrm{mg} / \mathrm{l})$ from a known standard. In this work $2.0 \mathrm{ml}$ of each sample mixture and $2.0 \mathrm{ml}$ of $25.0 \mathrm{mg} / 1$ standard was taken, mixed together and injected. Due to the dilution the actual concentration becomes $12.5 \mathrm{mg} / \mathrm{l}$. The observed concentrations and the known concentration are divided and then multiply by 100 to obtain the $\%$ of recoveries.

Statistical analysis: A descriptive analyses encompassing means, median, standard errors and coefficient of variation were computed. A one way analysis of variance (ANOVA) was carried out using Microsoft Excel 10 at a significance level of 5\%. The Least Significant Difference (LSD) test was used to locate differences in means.

\section{Results and Discussion}

HPLC is the most convenient and accurate technique for analysis bulk and finished pharmaceutical products. A RP-HPLC method has been developed and 
validated as per ICH, USP and FDA guidelines for determination of the sodium benzoate by using the mobile phase comprising of sodium acetate buffer $(\mathrm{pH}$ $=4)$ and acetonitrile in the ratio of $80: 20(\mathrm{v} / \mathrm{v})$ over C18 column at $37^{\circ} \mathrm{C}$. The flow rate was at $1.0 \mathrm{ml} / \mathrm{min}$ and the eluent was monitored by UV detector at $254 \mathrm{~nm}$. The retention time of sodium benzoate was $8.01 \pm 0.2$ min (Figures 1 and 2). Table 2 shows the different concentration $(5,10,20 \mu \mathrm{g} / \mathrm{ml})$ of sodium benzoate and their respective area in the chromatograms.

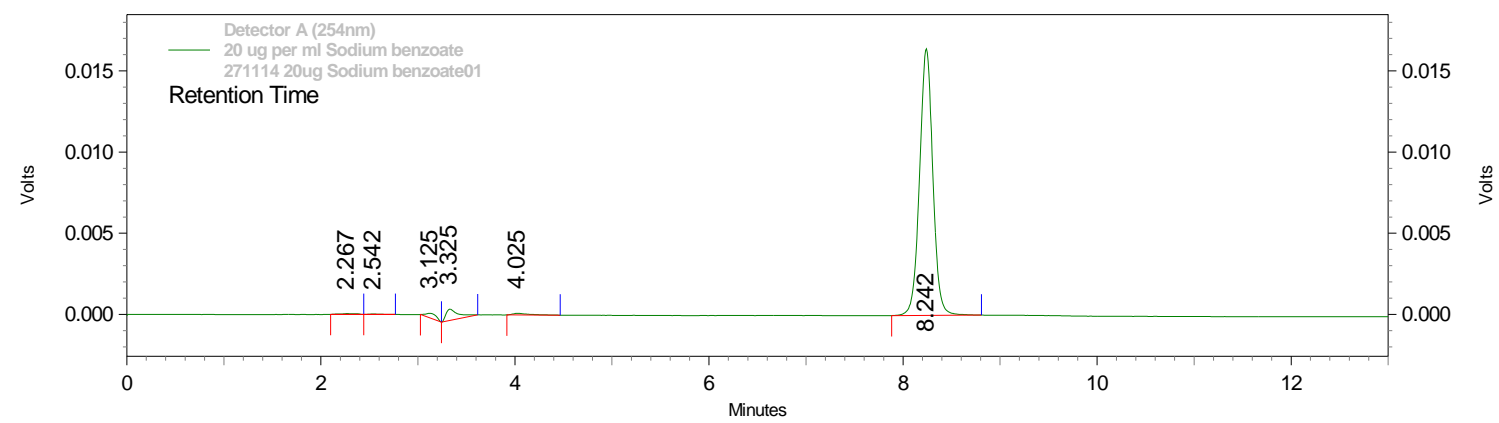

Figure 1. HPLC Chromatogram of $20 \mu \mathrm{g} / \mathrm{l}$ sodium benzoate standard solution. The retention for the peak of sodium benzoate in standard solution was 8.24 minutes.

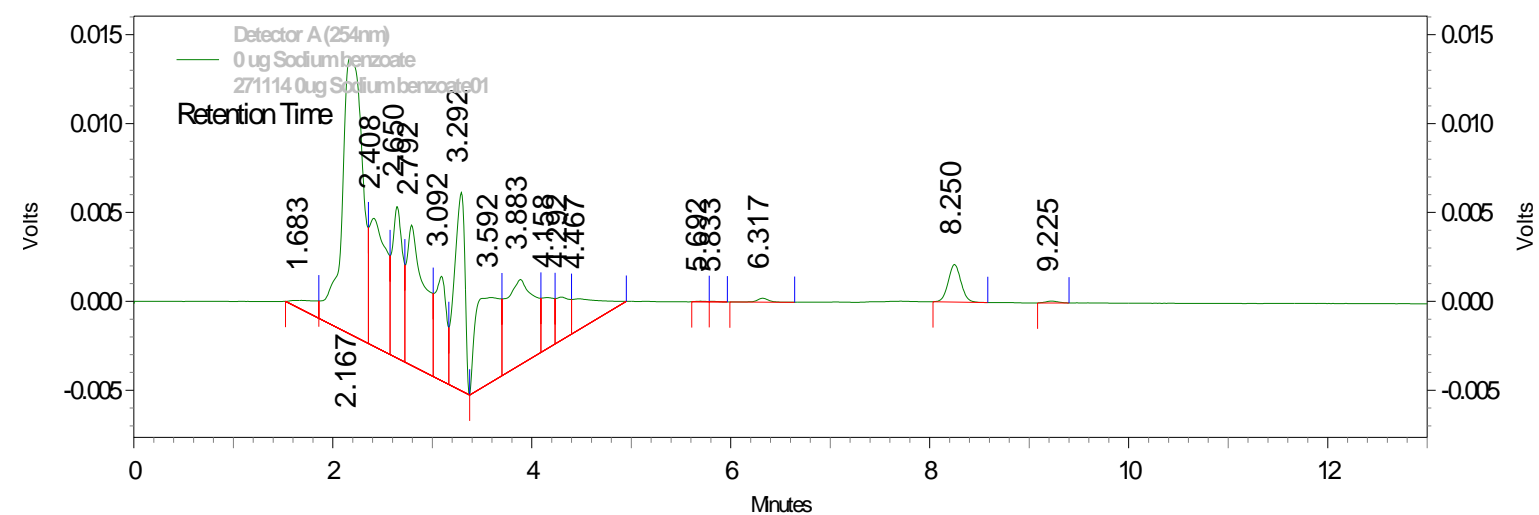

Figure 2. HPLC Chromatogram of $20 \mu \mathrm{g} / 1$ sodium benzoate sample solution. The retention for the peak of sodium benzoate in sample solution was 8.25 minutes.

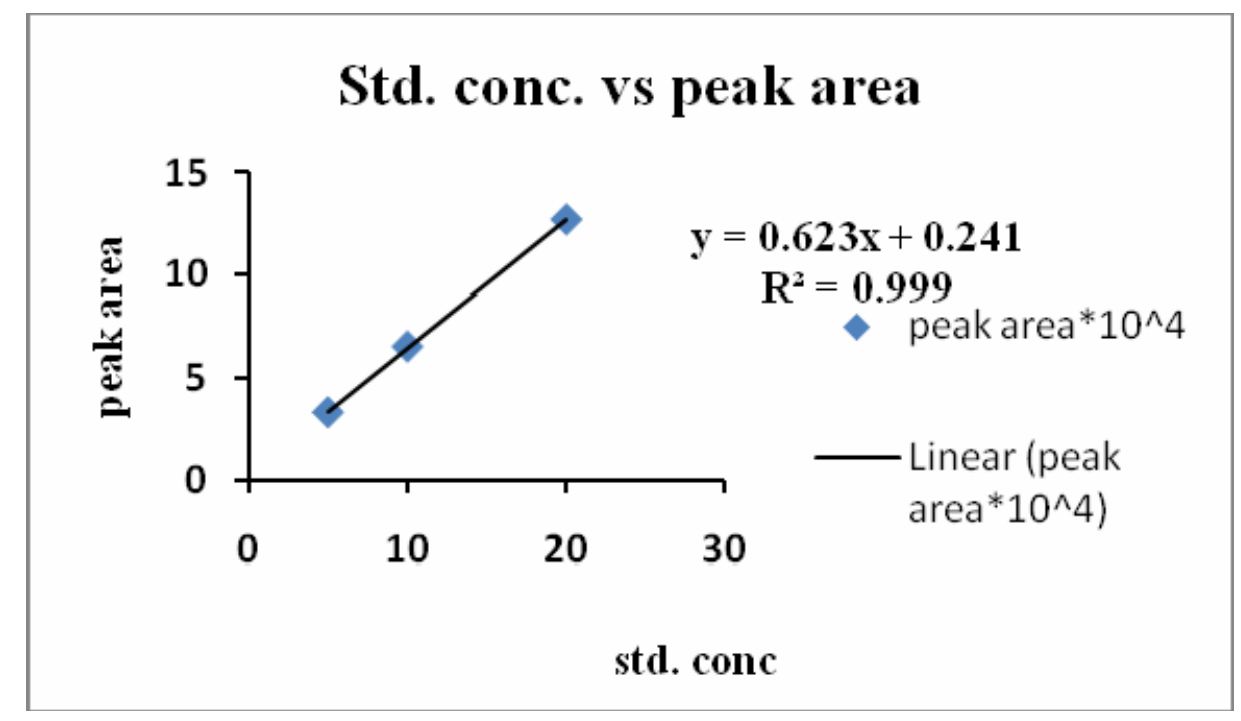

Figure 3. Calibration curve for the sodium benzoate standard solution. 


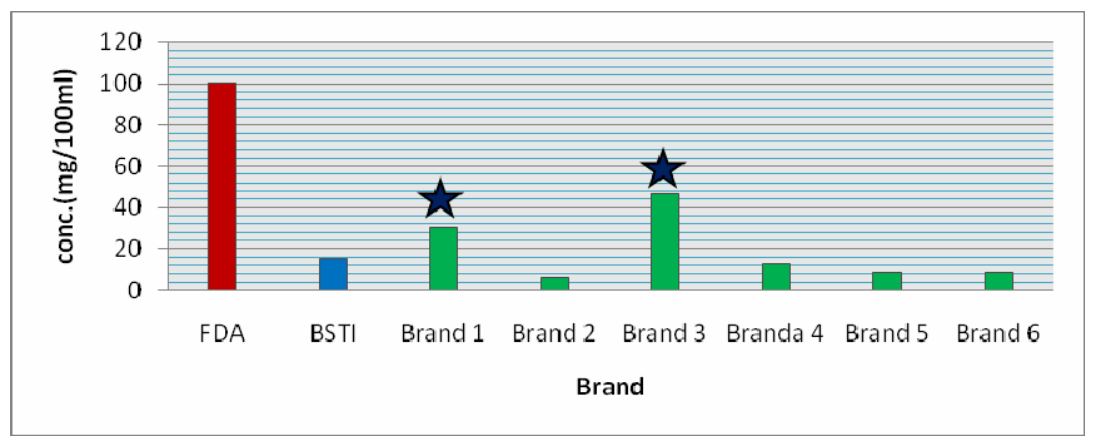

Figure 4. Comparison of sodium benzoate concentration of different brands of juices with the standard range.

Table 1. Concentration of sodium benzoate prepared in standard solution

\begin{tabular}{cccccc}
\hline Name & STD 0 $(\mu \mathrm{g} / \mathrm{ml})$ & STD 1 $(\mu \mathrm{g} / \mathrm{ml})$ & STD 2 $(\mu \mathrm{g} / \mathrm{ml})$ & STD 3 $(\mu \mathrm{g} / \mathrm{ml})$ & STD 4 $(\mu \mathrm{g} / \mathrm{ml})$ \\
\hline Sodium benzoate & 0.0 & 5.0 & 10.0 & 20.0 & 40.0 \\
\hline
\end{tabular}

Table 2. Different concentrations of sodium benzoate standard and their peak area.

\begin{tabular}{cccc}
\hline Std conc. $(\mu \mathrm{g} / \mathrm{ml})$ & Peak area*10^4 & Found conc. & Recovery $\%$ \\
\hline 5 & 3.32 & 4.942215088 & 98.84430177 \\
10 & 6.54 & 10.11075441 & 101.1075441 \\
20 & 12.69 & 19.9823435 & 99.9117175 \\
& Mean & & 99.95452113 \\
& Std & & 1.132228169 \\
\hline
\end{tabular}

Table 3. Analytical characteristics of HPLC method

\begin{tabular}{ll}
\hline Parameter & Value \\
\hline Accuracy & $99.95 \pm 1.13$ \\
Slope & 0.623 \\
Intercept & 0.241 \\
Linearity range & $4.94 \mu \mathrm{g} / \mathrm{ml}$ to $19.98 \mu \mathrm{g} / \mathrm{ml}$ \\
Correlation coefficient & 0.999864 \\
SE of intercept & 0.09 \\
SD of intercept & 0.144 \\
LOD & $0.00076 \mathrm{mg} / 100 \mathrm{ml}$ \\
LOQ & $0.0231 \mathrm{mg} / 100 \mathrm{ml}$ \\
\hline
\end{tabular}

Table 4. Level of sodium benzoate in brand-1 to brand-9 juices.

\begin{tabular}{lccc}
\hline \multicolumn{4}{c}{ Level of sodium benzoate $(\mathrm{mg} / 100 \mathrm{ml})$} \\
\hline Sample & Shop-1 & Shop-2 & Shop-3 \\
\hline Brand -1 & $35.11 \pm 1.94$ & $28.04 \pm 0.52$ & $28.10 \pm 4.86$ \\
Brand -2 & $5.45 \pm 1.04$ & $6.81 \pm 0.21$ & $7.16 \pm 0.24$ \\
Brand -3 & $47.53 \pm 1.61$ & $46.77 \pm 0.49$ & $46.56 \pm 0.31$ \\
Brand $-4^{\mathrm{a}}$ & $12.05 \pm 1.69$ & $12.98 \pm 0.09$ & $12.43 \pm 1.14$ \\
Brand -5 & $7.57 \pm 0.54$ & $8.94 \pm 0.88$ & $7.85 \pm 0.70$ \\
Brand -6 & $8.65 \pm 0.32$ & $8.7 \pm 0.46$ & $8.39 \pm 0.20$ \\
Brand -7 & $\mathrm{Nd}$ & $\mathrm{Nd}$ & $\mathrm{Nd}$ \\
Brand -8 & $\mathrm{Nd}$ & $\mathrm{Nd}$ & $\mathrm{Nd}$ \\
Brand -9 & $\mathrm{Nd}$ & $\mathrm{Nd}$ & $\mathrm{Nd}$ \\
\hline
\end{tabular}

$\mathrm{Nd}=$ not detected, $\mathrm{a}=$ claimed no preservative 
Table 5. Summary of the concentration of sodium benzoate $(\mathbf{m g} / 100 \mathrm{ml})$ in all selected brand of juices.

\begin{tabular}{lcccccc}
\hline Sample & \multicolumn{2}{c}{ Concentration of sodium benzoate $(\mathrm{mg} / 100 \mathrm{ml})$} & Mean & SD & CV (\%) \\
\hline Brand 1 & 35.11 & 28.04 & 28.10 & $30.41^{\mathrm{c}}$ & 4.06 & 13.36 \\
Brand 2 & 5.45 & 6.81 & 7.16 & $6.47^{\mathrm{a}}$ & 0.90 & 0.0013 \\
Brand 3 & 47.53 & 46.77 & 46.56 & $46.95^{\mathrm{d}}$ & 0.51 & 1.086 \\
Brand 4 & 12.05 & 12.98 & 12.43 & $12.48^{\mathrm{b}}$ & 0.46 & 3.68 \\
Brand 5 & 7.57 & 8.94 & 7.85 & $8.12^{\mathrm{a}}$ & 0.72 & 8.86 \\
Brand 6 & 8.65 & 8.7 & 8.39 & $8.58^{\mathrm{a}}$ & 0.16 & 1.86 \\
\hline
\end{tabular}

Number in rows followed by different superscript are significantly different at $\mathrm{p}<0.005$.

$\mathrm{b}, \mathrm{c}, \mathrm{d}, \mathrm{e}=$ least significant difference.

Table 6. Descriptive statistics of mango juices.

\begin{tabular}{lllllllll}
\hline Samples & $\begin{array}{l}\text { Number of } \\
\text { samples } \\
\text { used }\end{array}$ & $\begin{array}{l}\text { Mean Conc. } \\
\text { of sodium } \\
\text { benzoate } \\
(\mathrm{mg} / 100 \mathrm{ml})\end{array}$ & Variance & $\begin{array}{l}\text { Std. } \\
\text { deviation }\end{array}$ & SEM & $\begin{array}{l}\text { CV } \\
(\%)\end{array}$ & $\begin{array}{l}\text { Min. level of } \\
\text { sodium } \\
\text { benzoate }\end{array}$ & $\begin{array}{l}\text { Max } \\
\text { level of sodium } \\
\text { benzoate }\end{array}$ \\
\hline $\begin{array}{l}\text { Mango } \\
\text { juices }\end{array}$ & 27 & 18.83 & 238.25 & 15.43 & 3.63 & 81.94 & 5.45 & 47.53 \\
\hline
\end{tabular}

$\mathrm{SEM}=$ standard error of mean, $\mathrm{CV}=$ coefficient of variation, $\mathrm{Min}=$ minimum $\mathrm{Max}=$ maximum, Conc. $=$ Concentration.

Table 7. \% Recovery of sodium benzoate from spiked sample.

\begin{tabular}{cccc}
\hline Sample & $\begin{array}{c}\text { Concentration before spike } \\
(\mathrm{mg} / 100 \mathrm{ml})\end{array}$ & $\begin{array}{c}\text { Spiked level } \\
(\mu \mathrm{g} / \mathrm{ml})\end{array}$ & $\begin{array}{c}\text { \% Recovery } \\
\text { (Mean } \pm \mathrm{SD})\end{array}$ \\
\hline Brand 1 & 35.11 & 2.5 & $98.01 \pm 1.91$ \\
& 28.04 & 5.0 & $92.04 \pm 1.98$ \\
& 28.10 & 7.5 & $97.32 \pm 1.53$ \\
\hline
\end{tabular}

The calibration curve (Figure 3) for sodium benzoate was obtained by plotting the peak areas of different concentrations of working standard solutions (Table 1) prepared from the stock solutions. A very good linearity for sodium benzoate was obtained as it is presented in figure 3 with an excellent regression factor (0.9999). Linear regression line was obtained $y=0.623 x+0.241$. Table 7 shows the $\%$ recovery of brand-1 juices. The \% recovery of three concentrations was $98.01 \pm 1.91,92.04 \pm 1.98$ and $97.32 \pm 1.53$.

Table 5 shows the concentrations of sodium benzoate $(\mathrm{mg} / 100 \mathrm{ml})$ in the tested juices. The lavel of sodium benzoate (SB) in brand-1 was $30.41 \pm 4.06$ $\mathrm{mg} / 100 \mathrm{ml}$. There was no significant difference between the lavel of SB in brand-2, brand-5 and brand6 which was $6.47 \pm 0.90 \mathrm{mg} / 100 \mathrm{ml}, 8.12 \pm 0.72 \mathrm{mg} / 100$ $\mathrm{ml}$ and $8.58 \pm 0.16 \mathrm{mg} / 100 \mathrm{ml}$, respectively. Brand -4 and brand-7 juices claimed that there was no preservative but in brand-4 juices small amount of sodium benzoate was obtained as $12.48 \pm 0.46 \mathrm{mg} / 100 \mathrm{ml}$ as well as brand-7 juices followed their claim but may used other preservatives.

Figure 4 shows that the might have sodium benzoate concentration from all brands of juices were within the range according to US FDA standard range$0.1 \%(100 \mathrm{mg} / 100 \mathrm{ml})$. But according to the BSTI standard range- $150 \mathrm{ppm}(15 \mathrm{mg} / 100 \mathrm{ml})$, brand-1 juice exceed the level of sodium benzoate as twice which was $30.41 \mathrm{mg} / 100 \mathrm{ml}$. Brand-3 juices also exceed the level of sodium benzoate as higher rate which was $46.95 \mathrm{mg} / 100 \mathrm{ml}$ when compared with the BSTI range. Brand-2, brand-4, brand-5 and brand- 6 did not violate the legal limit of BSTI.

\section{Conclusion}

This work was based on a simple, selective and rather fast RP-HPLC method for the determination of the levels of sodium benzoate in mango juices available 
in Tangail region, Bangladesh. The results showed that sodium benzoate is a common preservative used by producers in the mango juices industry and that the concentration of sodium benzoate varied between different brands of mango juices. The described extraction procedures and analytical method seems to fulfill the criteria to achieve accurate and precise results for the analysis of sodium benzoate in the matrices under study. The extraction procedures described is economic, time saving and easy to carry out. The general detection of sodium benzoate in all the samples implies that this is the most frequently used preservatives by the manufactures. But it was found that some of the brands of juices used excess amount of sodium benzoate which is harmful for our health. The name of the preservatives used in juice products and their specific quantity should be declared on the label. The government authorized agency such as Bangladesh Council of Scientific and Industrial Research and Bangladesh Standard and Testing Institute should take control and regularly monitor to check the level of sodium benzoate in all brands of juices.

\section{References}

Branen, A.L. and Haggerty, R.J. 2002. Introduction to food additives. (In Branen, A.L., Davidson, P.M., Salminen, S. \& Thorngate III, J.H., eds. Food additives. 2nd ed. New York: Marcel Dekker. pp. 1-9.

Code of Federal Regulations Title 21, US Government Printing Office, Washington, DC, Revised 1 April, 1999, Section: 184.1733, sodium benzoate, Section: 182.3640, potassium sorbate. [Available on-line at: http: / /www.access.gpo.gov / nara / cfr / cfr-table-search.html].

Hannuksela, M. and Haahtela, T. 1987. Hypersensitivity reactions to food additives. Allergy 42, 561-575.

Jr, H.M.P. and Grether, M.T. 2000. Rapid high-performance liquid chromatography method for the analysis of sodium benzoate and potassium sorbate in foods, $J$. Chromatogr. A, 883, 299-304.

Juhlin, L. 1981. Recurrent urticaria: clinical investigation of 330 patients. Brit. J. Dermatol.104, 369-381.

Juhlin, L., Michaelsson, G., and Zeterstrom, O. 1972. Urticaria and asthma induced by food and drug additives in patients with aspirin hypersensitivity. J. Allergy Clin. Immunol. 50, 92.
Kayshar, M.S., Saifullah, M., Rahman, A. and Uddin, M.B. 2014. An overview of quality status of selected commercial brands of juices and jams based on public perception and laboratory analysis. J. Bangladesh Agril. Univ.12, 183-188.

Lahti, A., V€a€an€anen, A., Kokkonen, E. L., and Hannuksela, M. 1987. Acetylsalicyclic acid nonimmunologic contact urticaria. Cont. Dermatitis, 16, 133-135.

Lalita, K.G. and Glen, D.L. 1993. Benzene production from decarboxylation of benzoic acid in the presence of ascorbic acid and a transition-metal catalyst J. Agric. Food Chem. 41, 693-695.

LuÈck, F. 1990. Food applications of sorbic acid and its salts. Food Addit. Contam.7, 711-715.

Michaelsson, G.and Juhlin, L. 1973. Urticaria induced by preservatives and dye additives in foods and drugs. Brit. J. Dermatol. 88, 525-532.

Rahman, M. A., Sultan, M. Z., Rahman, M. S. and Rashid, M. A.2015. Food adulteration: A serious public health concern in Bangladesh. Bangladesh Pharm. J. 18, 1-7.

Rademaker, M., and Forsyth, A. 1989. Contact dermatitis in children. Cont. Dermatitis, 20, 104-107.

Saad, B., Bari, M.F., Saleh, M. I., Ahmad, K., and Talib, M.K.M. 2005. Simultaneous determination of preservatives (benzoic acid, sorbic acid, methylparaben and propylparaben) in foodstuffs using high-performance liquid chromatography. J. Chromatogr. 1073, 393-397.

Safford, R. J., Basketter, D. A., Allenby, C. F., \& Goodwin, B. F. J. 1990. Immediate contact reactions to chemicals in the fragrance mix and a study of the quenching action of eugenol. Brit. J. Dermatol.123, 595-606.

Sloan, A.E. 2004. Flavours of the future. Food technol. 58, 14.

Tfouni, S.A.V. and Toledo,C.F. 2002. Determination of benzoic and sorbic acids in Brazilian foods. Food control. 13, 117-123.

WHO (1996). Toxicological Evaluation of Certain Food Additives. Prepared by the 46th Meeting of the Joint FAO/WHO Expert Committee on Food Additives (JECFA). WHO Food Additives Series 37. Geneva: WHO; 1996. Available from URL. 